\title{
Increased soil organic carbon storage in Chinese terrestrial ecosystems from the 1980 s to the 2010 s
}

\author{
XU Li ${ }^{1},{ }^{*} Y U$ Guirui ${ }^{1,2}, \mathrm{HE}$ Nianpeng ${ }^{1,2}$
}

1. Key Laboratory of Ecosystem Network Observation and Modeling, Institute of Geographic Sciences and Natural Resources Research, CAS, Beijing 100101, China;

2. College of Resources and Environment, University of Chinese Academy of Sciences, Beijing 100049, China

\begin{abstract}
Soil stores a large amount of the terrestrial ecosystem carbon (C) and plays an important role in maintaining global $\mathrm{C}$ balance. However, very few studies have addressed the regional patterns of soil organic carbon (SOC) storage and the main factors influencing its changes in Chinese terrestrial ecosystems, especially using field measured data. In this study, we collected information on SOC storage in main types of ecosystems (including forest, grassland, cropland, and wetland) across 18 regions in China during the 1980s (from the Second National Soil Survey of China, SNSSC) and the 2010s (from studies published between 2004 and 2014), and evaluated its changing trends during these 30 years. The SOC storage $(0-100 \mathrm{~cm})$ in Chinese terrestrial ecosystems was $83.46 \pm 11.89 \mathrm{Pg} \mathrm{C}$ in the $1980 \mathrm{~s}$ and $86.50 \pm 8.71 \mathrm{Pg} \mathrm{C}$ in the 2010s, and the net increase over the 30 years was $3.04 \pm 1.65$ $\mathrm{Pg} \mathrm{C}$, with an overall rate of $0.101 \pm 0.055 \mathrm{Pg} \mathrm{C} \mathrm{yr}^{-1}$. This increase was mainly observed in the topsoil $(0-20 \mathrm{~cm})$. Forests, grasslands, and croplands SOC storage increased $2.52 \pm 0.77$, $0.40 \pm 0.78$, and $0.07 \pm 0.31 \mathrm{Pg} \mathrm{C}$, respectively, which can be attributed to the several ecological restoration projects and agricultural practices implemented. On the other hand, SOC storage in wetlands declined $0.76 \pm 0.29 \mathrm{Pg} \mathrm{C}$, most likely because of the decrease of wetland area and SOC density. Combining these results with those of vegetation $C$ sink $(0.100$ $\mathrm{Pg} \mathrm{C} \mathrm{yr}{ }^{-1}$ ), the net $\mathrm{C}$ sink in Chinese terrestrial ecosystems was about $0.201 \pm 0.061 \mathrm{Pg} \mathrm{C} \mathrm{yr}^{-1}$, which can offset $14.85 \%-27.79 \%$ of the fossil fuel C emissions from the 1980 s to the 2010 s. These first estimates of soil $\mathrm{C}$ sink based on field measured data supported the premise that China's terrestrial ecosystems have a large $C$ sequestration potential, and further emphasized the importance of forest protection and reforestation to increase SOC storage capacity.
\end{abstract}

Keywords: Chinese terrestrial ecosystems; change; storage; soil organic carbon

\section{Introduction}

Soil stores about $80 \%$ of the carbon (C) present in the global terrestrial ecosystems (Post et

Received: 2018-03-30 Accepted: 2018-06-22

Foundation: The Chinese Academy of Sciences Strategic Priority Research Program, No.XDA19020302, National Key Research Project of China, No.2016YFC0500202; National Natural Science Foundation of China, No.31290221, No.41571130043, No.31570471

Author: Xu Li, PhD and Assistant Professor, specialized in global carbon cycle. E-mail: xuli@igsnrr.ac.cn

*Corresponding author: Yu Guirui, PhD and Professor, E-mail: yugr@igsnrr.ac.cn 
al., 1982). Soil organic carbon (SOC) pools affect global food security directly or indirectly by supplying nutrients, improving soil fertility, and fixing and decomposing pollutants (Cox et al., 2000; Lal, 2004b), and changes in SOC storage can affect global climate to some extent, as a source or sink of atmospheric $\mathrm{CO}_{2}$. In fact, $\mathrm{C}$ sequestration capacity of terrestrial ecosystems, especially soil, has been considered an environmentally friendly and cost-effective way to moderate the increased concentration of atmospheric $\mathrm{CO}_{2}$. Therefore, accurate evaluations of SOC storage and its changing trends at a regional scale are important to effectively manage terrestrial ecosystems in a global effort to decrease the rate at which $\mathrm{CO}_{2}$ accumulates in the atmosphere (Piao et al., 2009).

Based on forest inventories, grassland resources surveys, field measurements, and remote-sensing data, some scientists have assessed terrestrial ecosystem $\mathrm{C}$ storage and its changing trends at regional and global scales (Pacala et al., 2001; Janssens et al., 2003; Piao et al., 2009; Pan et al., 2011). In China, most studies focused on vegetation C storage (Fang et al., 2007; Pan et al., 2011) and only a few examined changing trends in SOC storage (Wang et al., 2003; Xie et al., 2007), although some studies estimated SOC storage at regional scales (Wu et al., 2003; Yang et al., 2007; Xu et al., 2015; Yang et al., 2017) (Table 1). Furthermore, the estimates of SOC storage both at global and regional scale are still uncertain, with the total SOC storage in world's soils varying from 1395 to $2200 \mathrm{Pg}$ C (Bohn, 1982; Eswaran et al., 1993; Batjes, 1996; Jobbágy and Jackson, 2000), and the SOC storage in China ranging from 50 to $185.7 \mathrm{Pg}$ C (Fang et al., 1996; Pan, 1999; Yang et al., 2007) (Table 1). These wide ranges are mainly attributed to insufficient sampling (Piao et al., 2009; Schrumpf et al., 2011; Wiesmeier et al., 2012; Ni, 2013). Compared to vegetation inventories and remote-sensing data, which have been regularly obtained, periodic soil survey is scarce, resulting in the unavailability of contemporary soil $\mathrm{C}$ measurements (Hayes et al., 2012; Yang et al., 2014b). Thus, it is urgent to obtain additional robust estimates of SOC by using reliable data and optimized methods at regional or global scales.

Because China comprises a considerable part of the global terrestrial ecosystems, it is crucial to determine the global $\mathrm{C}$ balance in terms of SOC changes (increase or decrease). The government has implemented a series of ecological protection/restoration projects since the 1980s, such as the Three-North Shelter Forest Program, Yangtze River Shelter Forest Project, Zhujiang River Shelter Forest Project, South China Timber Production Project, and Natural Forest Protection Project, to restore or improve the ecological status of these habitats. In addition, many advanced agricultural practices have been implemented to increase crop production and soil improvement (Huang and Sun, 2006). Taken together, these projects have undoubtedly increased $\mathrm{C}$ sequestration capacity to tackle climate change (Wang et al., 2011; Liu et al., 2014b; Yang et al., 2014a; Ouyang et al., 2016), and a large increase in $\mathrm{C}$ storage, both in vegetation and in soil, has been anticipated. Although some studies assessed changes in vegetation $\mathrm{C}$, or changes in ecosystem $\mathrm{C}$ focusing on vegetation (Fang et al., 2007; Xu et al., 2007; Xin et al., 2009; Ma et al., 2010; Liang et al., 2015), it is virtually unknown how SOC storage changed in the past three decades in Chinese terrestrial ecosystems. Still, Yang et al. (2010) explored changes in SOC storage in northern China's grasslands, combining soil investigation data with historical records and Pan et al. (2010) and Yang et al. (2014a) explored changes in SOC storage across Chinese croplands and forests, respectively, based on published data. Therefore, understanding SOC storage changes in 


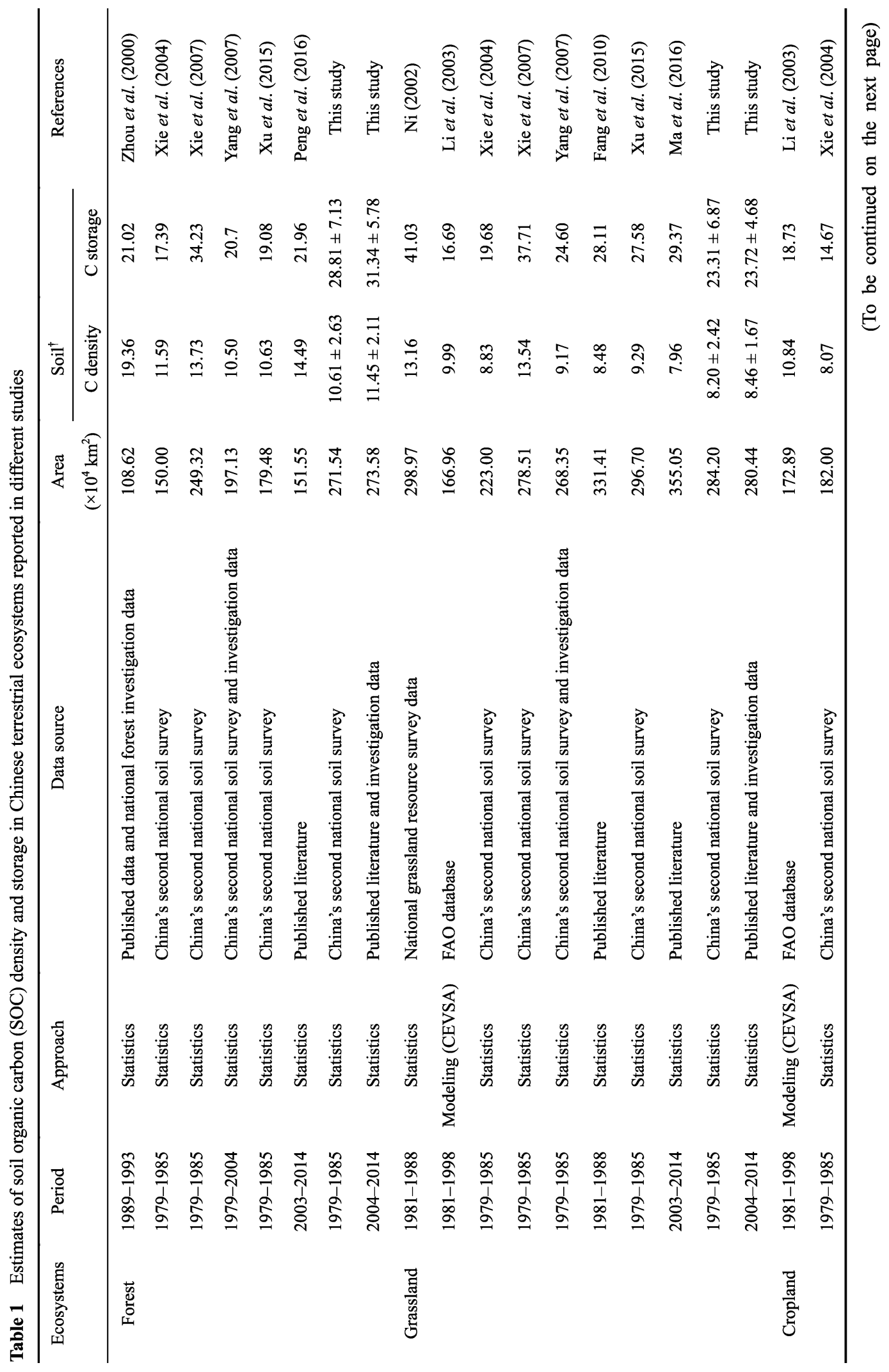


己

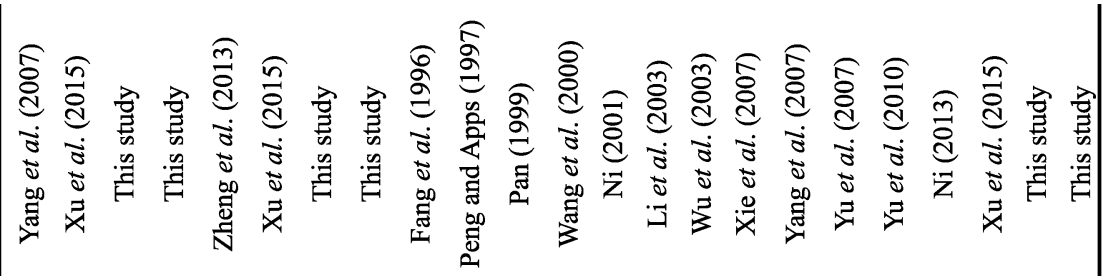

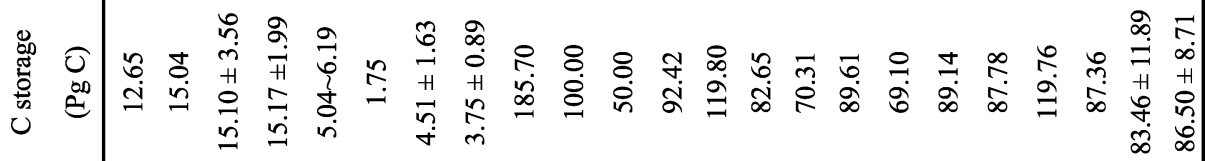

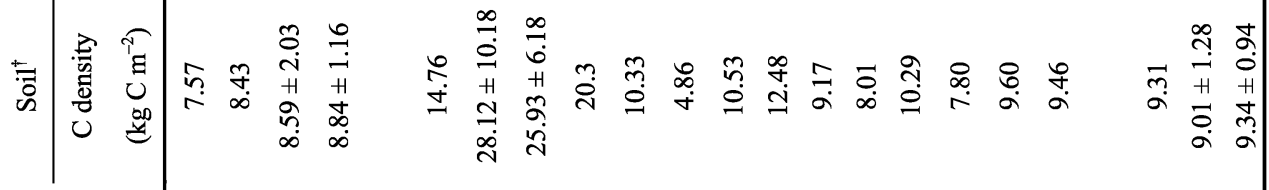

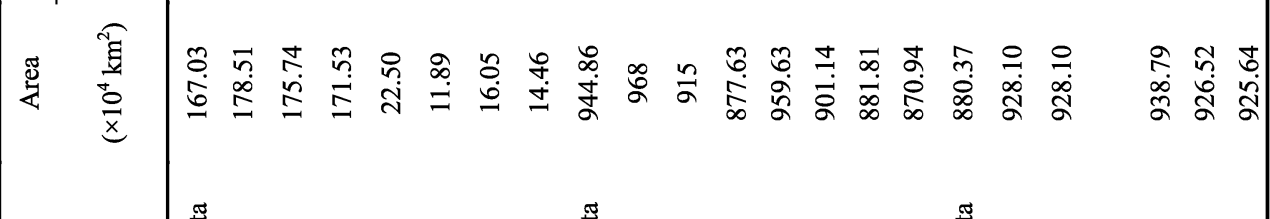

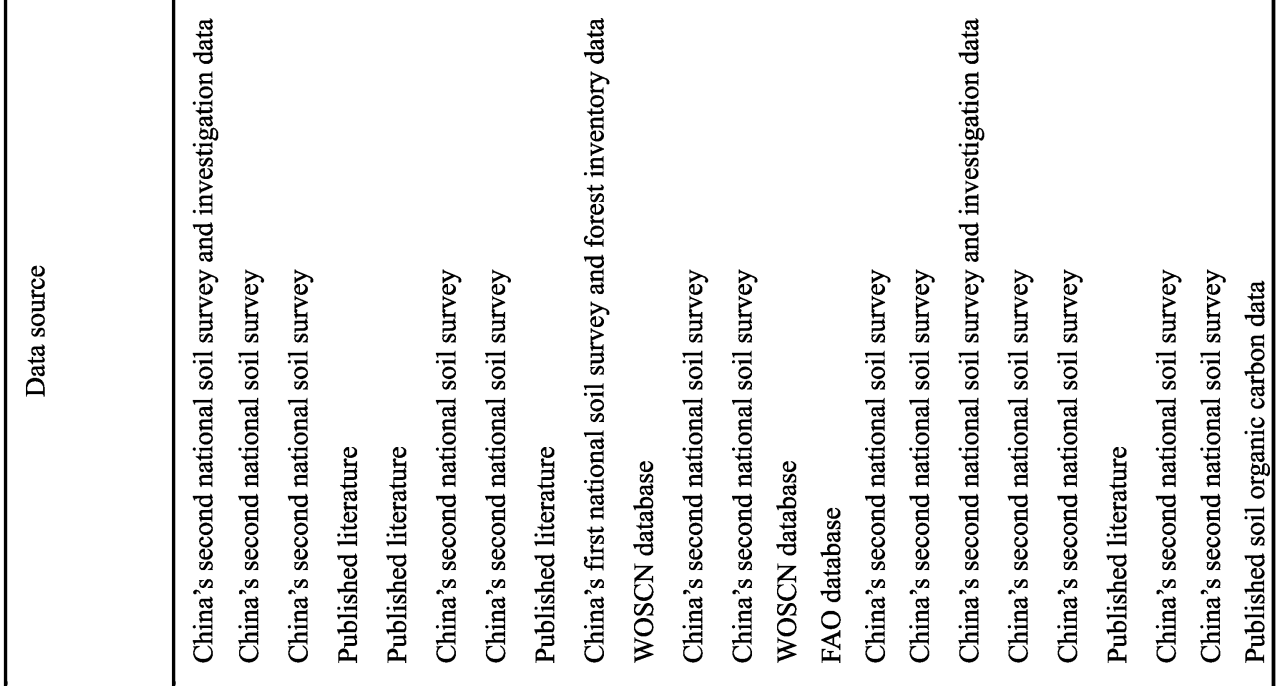

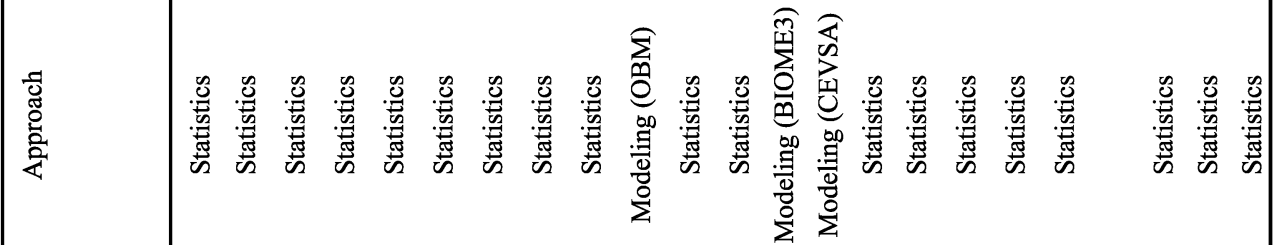

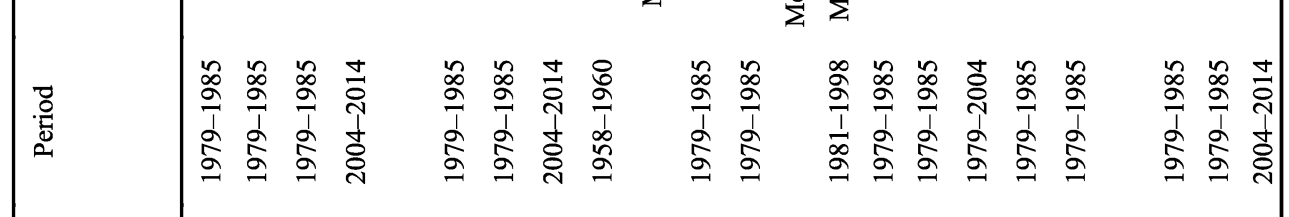

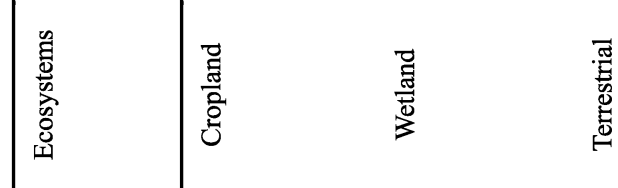


China's terrestrial ecosystems is imperative to accurately evaluate their capacity to sequester atmospheric $\mathrm{CO}_{2}$, as many studies suggested this is similar between soil and vegetation, or even higher in soil than in vegetation (Lal, 2004a).

In the present study, information on SOC storage in China recorded during the 1980s (8,897 soil profiles from the Second National Soil Survey of China (SNSSC)) and 2010s (7,683 soil profiles published between 2004 and 2014) for the main ecosystems (forest, grassland, cropland, and wetland ecosystems) and at different soil depths $(0-20 \mathrm{~cm}$ and 0-100 cm), were analyzed with three main objectives: 1) estimate SOC storage in Chinese terrestrial ecosystems during 1980s-2010s; 2) assess the increases in SOC storage from the 1980 s to the 2010 s; 3 ) reveal differences in soil C sequestration rates among forest, grassland, cropland, and wetland.

\section{Materials and methods}

\subsection{Data collection}

\subsubsection{Collection and compilation of the 2010s' data}

To estimate the current status of SOC storage in China, we compiled all the information available in studies considering SOC concentration/content published during the 2010s (i.e., from 2004 to 2014). Data were obtained from: (1) field investigated data published from 2004 to 2014, available in the China National Knowledge Infrastructure (CNKI, http://www.cnki.net) and International Scientific Indexing Web of Knowledge (ISI, http://apps.webofknowledge.com) databases, searching for 'SOC' in keywords or abstract; and (2) field-measured data obtained by personal correspondence. Data collected from papers were further screened based on the following rules: 1) data on SOC content must have been obtained through field investigations; 2) field investigations were carried out after 2000; and 3) SOC measuring methods were similar to those in the SNSSC (Xu et al., 2018). If geographical information was not available for sampling sites, we extracted their latitude and longitude with a digital map (http://map.tianditu.com), based on the description of the study site. The 805 papers selected encompassed the main ecosystems in China, namely forest, grassland, cropland, and wetland ecosystems. Specifically, the collected data included records for 7,683 soil samples (4536 samples for the 0-20 cm soil layer, and 3147 samples for the $0-100 \mathrm{~cm}$ soil layer; Figure 1 and Table 2).

\subsubsection{Collection of the 1980s' data}

To estimate the status of SOC storage in the 1980s, we collected 8897 soil profiles from the SNSSC, which was implemented in 1979-1985, and included information on geographic location, soil thickness $(\mathrm{cm})$, organic matter content $(\%)$, bulk density $\left(\mathrm{g} \mathrm{cm}^{-3}\right)$, rock content (\%), clay, silt and sand content (\%), and soil type (Wang et al., 2004). These soil profiles were standardized from soil survey treatises at the provincial and national scale (Figure 1 and Table 2).

\subsubsection{Division of ecological regions}

To explore regional differences in SOC storage changes, Chinese terrestrial ecosystems were divided into 18 ecological regions (Figure 1) based on climate and topography (Fu et al., 2001), named as follows: cold humid regions (R1), temperate humid regions (R2), temperate 
semi-humid regions (R3), temperate semi-arid regions (R4), temperate arid regions (R5), warm temperate arid regions (R6), Qinghai-Tibet Plateau frigid arid regions (R7), warm

(a) Ecological regions

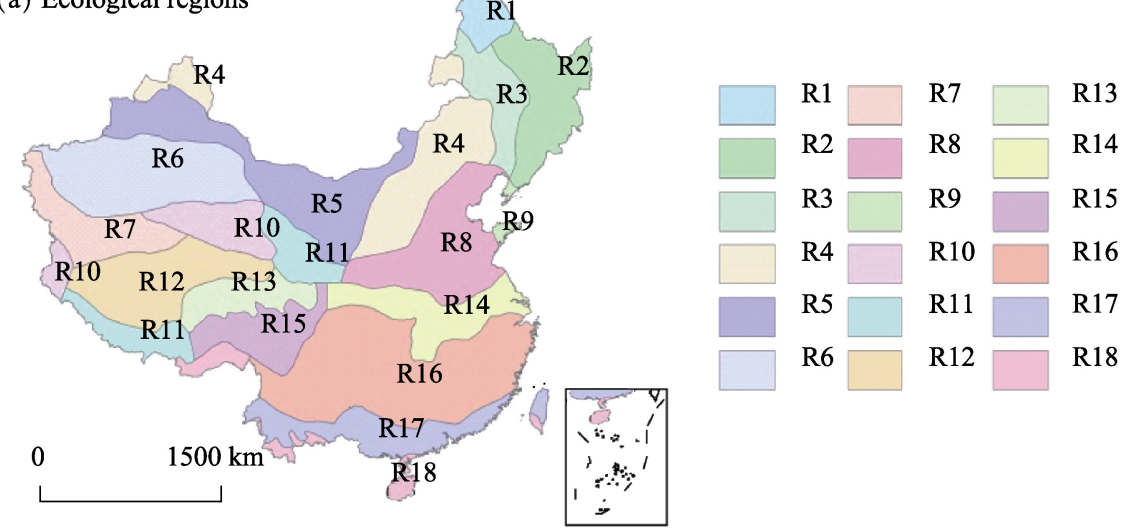

(b) $0-20 \mathrm{~cm}$ SOC (1980s)

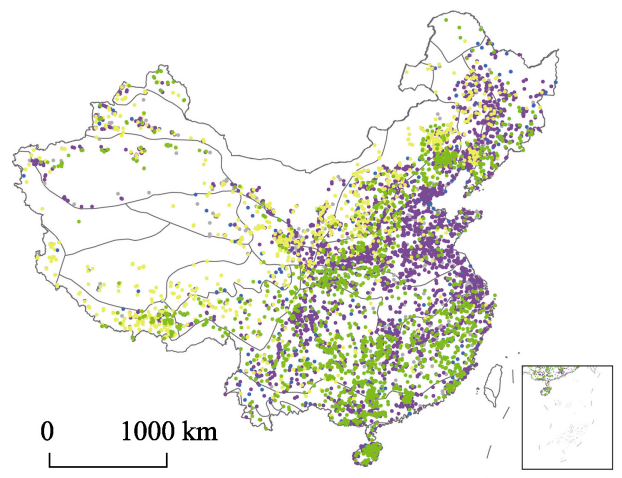

(d) $0-100 \mathrm{~cm} \mathrm{SOC}(2010 \mathrm{~s})$

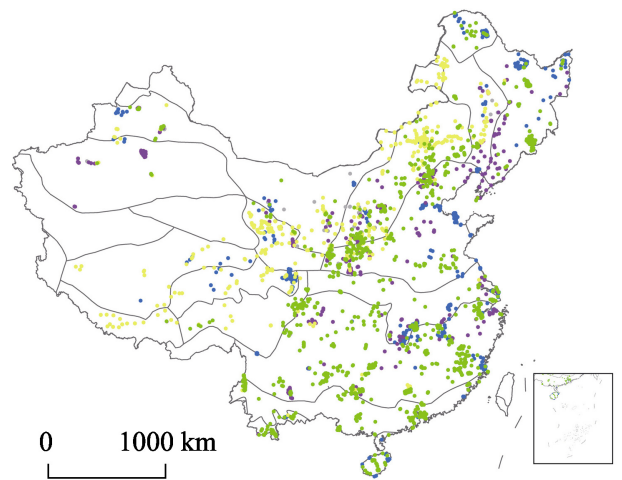

(c) $0-100 \mathrm{~cm} \mathrm{SOC}(1980 \mathrm{~s})$

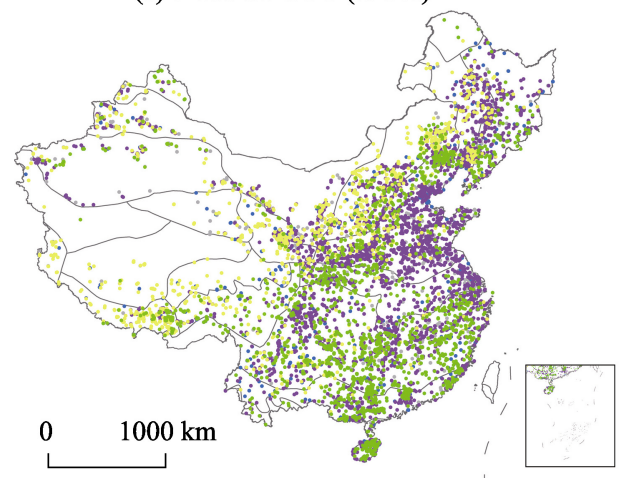

(e) $0-100 \mathrm{~cm} \operatorname{SOC}(2010 \mathrm{~s})$

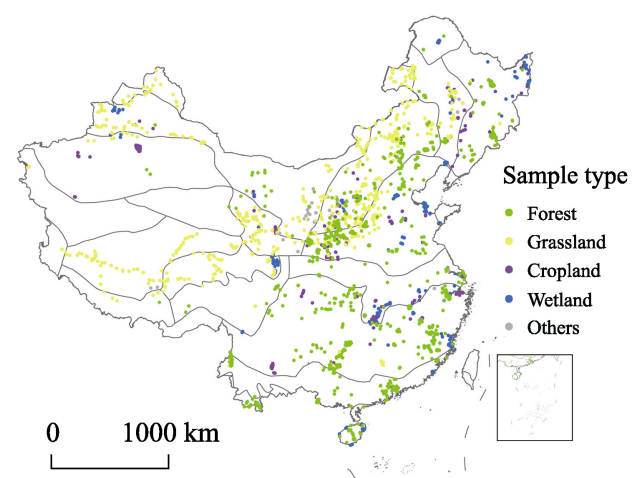

Figure 1 Regional division of China's terrestrial ecosystems and the distribution of soil samples collected in China in the 1980 s and 2010 s

R1, Cold humid regions; R2, Temperate humid regions; R3, Temperate semi-humid regions; R4, Temperate semi-arid regions; R5, Temperate arid regions; R6, Warm temperate arid regions; R7, Qinghai-Tibet Plateau frigid arid regions; R8, Warm temperate semi-humid regions; R9, Warm temperate humid regions; R10, Qinghai-Tibet Plateau temperate arid regions; R11, Qinghai-Tibet Plateau temperate semi-arid regions; R12, Qinghai-Tibet Plateau subfrigid semi-arid regions; R13, Qinghai-Tibet Plateau subfrigid semi-humid regions; R14, North subtropical humid regions; R15, Qinghai-Tibet Plateau temperate humid and semi-humid regions; R16, Mid-subtropical humid regions; R17, South subtropical humid regions; R18, Tropical humid regions 
Table 2 The properties of soil samples and SOC density $\left(\mathrm{kg} \mathrm{C} \mathrm{m}^{-2}\right)$ across different ecosystems of China in the 1980 s and 2010 s

\begin{tabular}{|c|c|c|c|c|c|c|c|c|c|c|c|}
\hline & & \multicolumn{5}{|c|}{$1980 \mathrm{~s}$} & \multicolumn{5}{|c|}{$2010 \mathrm{~s}$} \\
\hline & & Forest & Grassland & Cropland & Wetland & Others & Forest & Grassland & Cropland & Wetland & Others \\
\hline \multirow[t]{6}{*}{$0-20 \mathrm{~cm}$} & $\mathrm{~N}^{\dagger}$ & 1990 & 1367 & 4175 & 498 & 867 & 1861 & 931 & 840 & 796 & 108 \\
\hline & Min & 0.04 & 0.13 & 0.05 & 0.14 & 0.09 & $<0.01$ & 0.03 & 0.28 & 0.18 & 0.11 \\
\hline & Max & 15.02 & 16.94 & 17.09 & 57.42 & 12.26 & 13.59 & 13.40 & 7.91 & 23.75 & 6.28 \\
\hline & Mean & 3.93 & 3.39 & 2.95 & 7.11 & 2.52 & 4.48 & 4.06 & 3.03 & 5.60 & 1.72 \\
\hline & SD & 2.45 & 2.53 & 1.89 & 5.15 & 1.74 & 2.83 & 2.99 & 1.56 & 4.82 & 1.24 \\
\hline & $\mathrm{CV}$ & 0.62 & 0.74 & 0.64 & 0.72 & 0.69 & 0.63 & 0.74 & 0.51 & 0.86 & 0.72 \\
\hline \multirow[t]{6}{*}{$0-100 \mathrm{~cm}$} & $\mathrm{~N}$ & 1989 & 1349 & 4175 & 498 & 867 & 1344 & 842 & 544 & 328 & 89 \\
\hline & Min & 0.04 & 0.13 & 0.23 & 0.71 & 0.11 & 0.50 & 0.39 & 0.94 & 0.55 & 0.41 \\
\hline & Max & 55.87 & 30.84 & 49.89 & 176.17 & 40.98 & 34.66 & 30.01 & 22.44 & 85.12 & 27.50 \\
\hline & Mean & 10.11 & 8.56 & 8.49 & 23.80 & 7.06 & 10.12 & 8.23 & 8.16 & 14.87 & 5.96 \\
\hline & SD & 6.90 & 6.02 & 5.76 & 19.07 & 4.50 & 6.23 & 5.74 & 4.06 & 14.81 & 5.09 \\
\hline & $\mathrm{CV}$ & 0.68 & 0.70 & 0.68 & 0.80 & 0.64 & 0.62 & 0.70 & 0.50 & 0.99 & 0.85 \\
\hline
\end{tabular}

${ }^{\dagger} \mathrm{N}$, sample number; Min, Max and Mean, the minimum, maximum, and mean value of SOC density $\left(\mathrm{kg} \mathrm{C} \mathrm{m}^{-2}\right) ; \mathrm{SD}$, standard deviation; $\mathrm{CV}$, the coefficient of variation.

temperate semi-humid regions (R8), warm temperate humid regions (R9), Qinghai-Tibet Plateau temperate arid regions (R10), Qinghai-Tibet Plateau temperate semi-arid regions (R11); Qinghai-Tibet Plateau subfrigid semi-arid regions (R12), Qinghai-Tibet Plateau subfrigid semi-humid regions (R13), north subtropical humid regions (R14), Qinghai-Tibet Plateau temperate humid and semi-humid regions (R15), mid-subtropical humid regions (R16), south subtropical humid regions (R17), and tropical humid regions (R18) (Xu et al., 2018). Areas of the different ecosystems (forest, grassland, cropland, wetland, and others) within each ecological region in the two periods were extracted from the Chinese land cover data (Wu et al., 2014). The total area of terrestrial ecosystems in China, not including Taiwan Province and inland waters, covered approximately $9.25 \times 10^{6} \mathrm{~km}^{2}$.

\subsection{Data analysis}

\subsubsection{Calculation of SOC density}

In order to determine the $C$ sequestration rate at $0-20 \mathrm{~cm}$ and at $0-100 \mathrm{~cm}$ soil depths, we estimated SOC density and storage in both layers. SOC density $\left(\mathrm{kg} \mathrm{C} \mathrm{m}^{-2}\right)$ at $0-20 \mathrm{~cm}$ or $0-100 \mathrm{~cm}$ was calculated using equations (1) and (2):

$$
\begin{aligned}
\text { SOC density }= & \sum_{i=1}^{\mathrm{n}} \operatorname{SOC}_{i} \times B D_{i} \times D_{i} \times\left(1-\delta_{i}\right) \times 0.1 \\
& \operatorname{SOC}_{i}=\operatorname{SOM}_{i} \times 0.58
\end{aligned}
$$

where $S O C_{i}, B D_{i}, D_{i}, \delta_{i}$, and $S O M_{i}$ represent SOC content (\%), bulk density $\left(\mathrm{g} \mathrm{cm}^{-3}\right)$, soil depth $(\mathrm{cm})$, the volumetric percentage of the fraction $>2 \mathrm{~mm}(\%)$, and soil organic matter (SOM) content (\%), respectively, in soil layer $i$, and $n$ is the number of soil layers. SOM was converted to SOC using the constant 0.58 (Xie et al., 2007). The pedotransfer function was used to estimate bulk density from related SOC concentration in soil samples without bulk density records (Yang et al., 2007), and the mean value of rock fragment volume was used to 
substitute the same soil type without measured values.

\subsubsection{Calculation of SOC storage}

SOC storage in the 1980s and 2010s was calculated in two steps (Figure 2). After calculating SOC storage for the several ecological regions, these values were summed to estimate total SOC storage in China according to equation (3):

$$
\text { SOC storage }=\sum_{i=1}^{m} \sum_{j=1}^{n}\left(S O C D_{i j} \times S_{i j}\right)
$$

where $m$ and $n$ are the number of ecological regions and ecosystems, $S O C D_{i j}$ are SOC density of ecosystem $j$ in ecological region $i, S_{i j}$ is the surface area of ecosystem $j$ in ecological region $i$. For ecological regions where the number of samples within one of the ecosystems was less than 10, or where the spatial distribution of samples was extremely uneven (i.e., samples were concentrated in a single area), we combined samples from the same ecosystems in adjacent regions with similar climatic conditions to estimate SOC density (Xu et al., 2018).

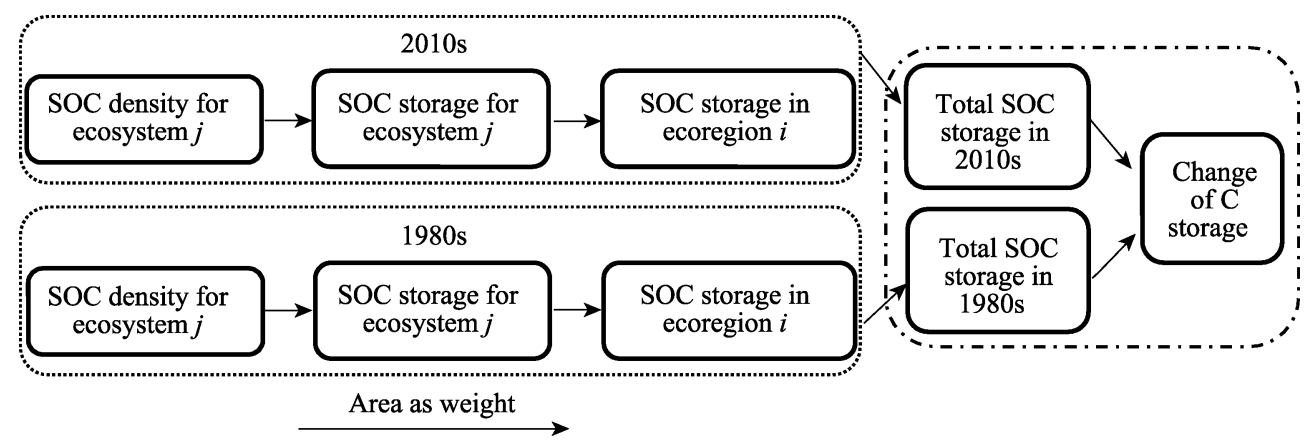

Figure 2 Flow diagram of soil organic carbon (SOC) storage change calculation during the 1980s-2010s

\subsubsection{Changes in SOC storage from the 1980s to the 2010s}

Changes in SOC storage $\left(\Delta V_{\mathrm{s}}, \mathrm{Pg} \mathrm{C} \mathrm{yr}^{-1}\right)$ was calculated according to equation (4):

$$
\Delta V_{\mathrm{s}}=\frac{\operatorname{SOCS}(2010 \mathrm{~s})-\operatorname{SOCS}(1980 \mathrm{~s})}{30}
$$

where SOCS(2010s) and SOCS(1980s) represent SOC storage (Pg C) in the 2010s and 1980s, respectively.

\section{Results}

\subsection{SOC density and storage in the 1980s and $2010 \mathrm{~s}$}

In the $1980 \mathrm{~s}$, SOC storage in the topsoil $(0-20 \mathrm{~cm})$ was approximately $30.94 \pm 3.93 \mathrm{Pg} \mathrm{C}$ and represented $37.07 \%$ of SOC storage in the $0-100 \mathrm{~cm}$ soil layer $(83.46 \pm 11.89 \mathrm{Pg} \mathrm{C})$ (Figure 3). The SOC storage in forest, grassland, cropland and wetland topsoil was $11.30 \pm$ $2.44,9.01 \pm 2.33,5.26 \pm 1.13$ and $1.36 \pm 0.44 \mathrm{Pg} \mathrm{C}$, respectively. In the $0-100 \mathrm{~cm}$ soil layer, SOC storage in forest, grassland, cropland, and wetland was $28.81 \pm 7.13,23.31 \pm 6.87$, $15.10 \pm 3.56$, and $4.51 \pm 1.63 \mathrm{Pg} \mathrm{C}$, respectively (Figure 4).

In the 2010s, SOC storage in the topsoil was about $34.62 \pm 3.71 \mathrm{Pg} \mathrm{C}$ and accounted for $40.02 \%$ of SOC storage in the $0-100 \mathrm{~cm}$ soil layer $(86.50 \pm 8.71 \mathrm{Pg} \mathrm{C})$ (Figure 2). In the topsoil, SOC storage in forest, grassland, cropland, and wetland was $13.93 \pm 2.66,10.06 \pm 2.19$, 

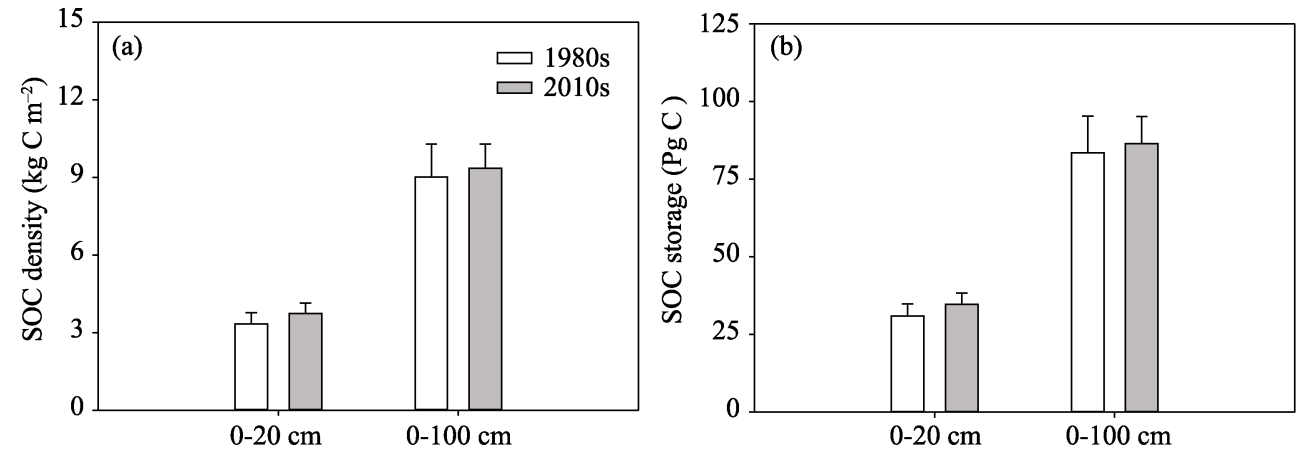

Figure 3 SOC density $\left(\mathrm{a}, \mathrm{kg} \mathrm{C} \mathrm{m}^{-2}\right)$ and storage (b, Pg C) in China during the $1980 \mathrm{~s}-2010 \mathrm{~s}$
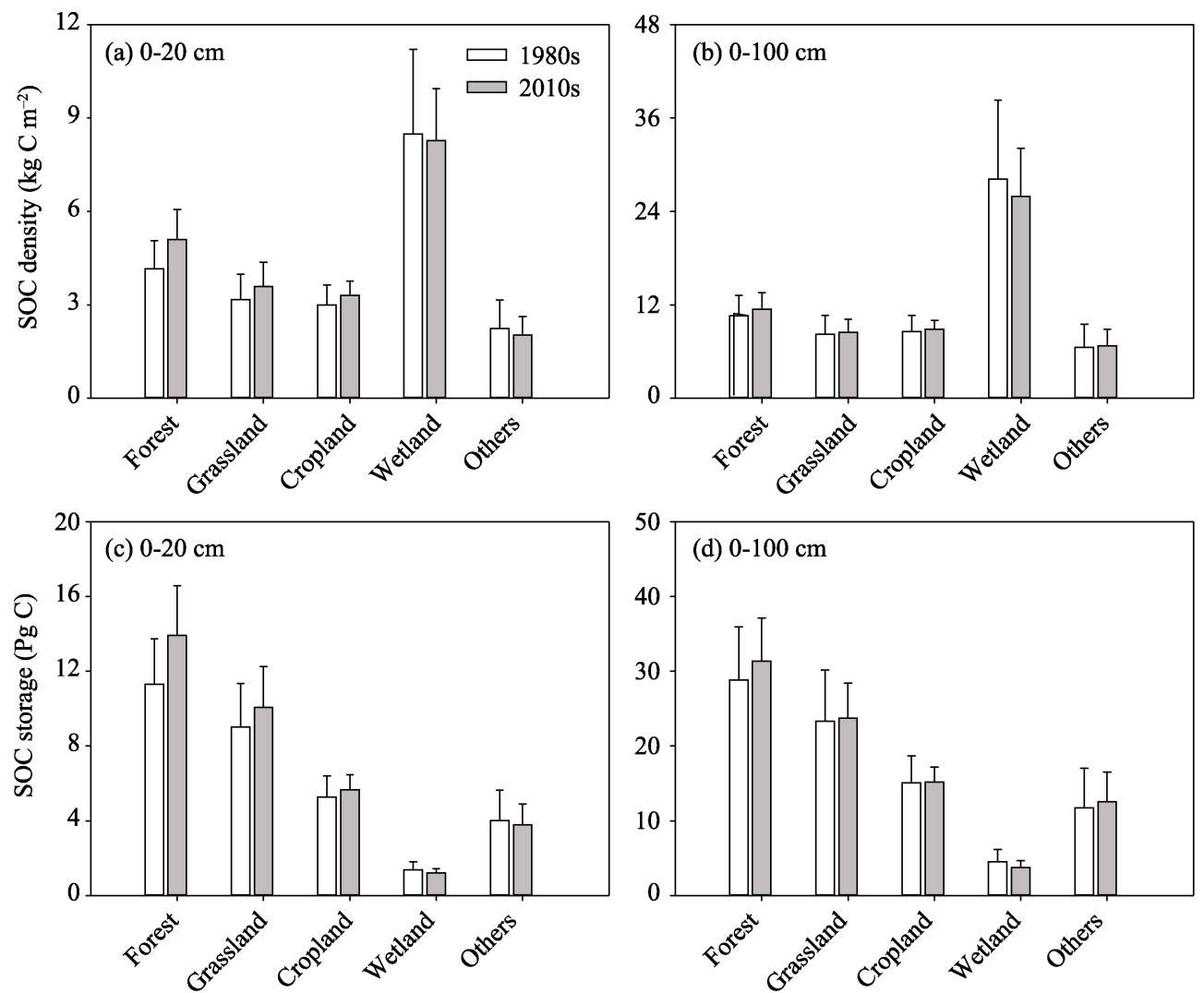

Figure 4 SOC density (a, b; $\left.\mathrm{kg} \mathrm{C} \mathrm{m}^{-2}\right)$ and storage (c, d; Pg C) across different ecosystems of China

$5.66 \pm 0.79$, and $1.20 \pm 0.24 \mathrm{Pg} \mathrm{C}$, respectively. For the $0-100 \mathrm{~cm}$ soil layer, SOC storage in forest, grassland, cropland, and wetland was $31.34 \pm 5.78,23.72 \pm 4.68,15.17 \pm 1.99$, and $3.75 \pm 0.89 \mathrm{Pg} \mathrm{C}$, respectively.

\subsection{Changes in SOC density and storage from the $1980 \mathrm{~s}$ to the $2010 \mathrm{~s}$}

From the $1980 \mathrm{~s}$ to the $2010 \mathrm{~s}$, China's SOC storage in $0-20 \mathrm{~cm}$ and $0-100 \mathrm{~cm}$ layers increased by about $3.68 \pm 0.53$ and $3.04 \pm 1.65 \mathrm{Pg} \mathrm{C}$, at rates of $0.123 \pm 0.018$ and $0.101 \pm$ $0.055 \mathrm{Pg} \mathrm{C} \mathrm{yr}^{-1}$, respectively (Figures 3 and $5 \mathrm{a}$ ). The increasing rate of SOC storage was higher in the $0-20 \mathrm{~cm}$ soil layer $(11.88 \%)$ than that in the $0-100 \mathrm{~cm}(3.64 \%)$ (Figure $5 \mathrm{~b})$. 

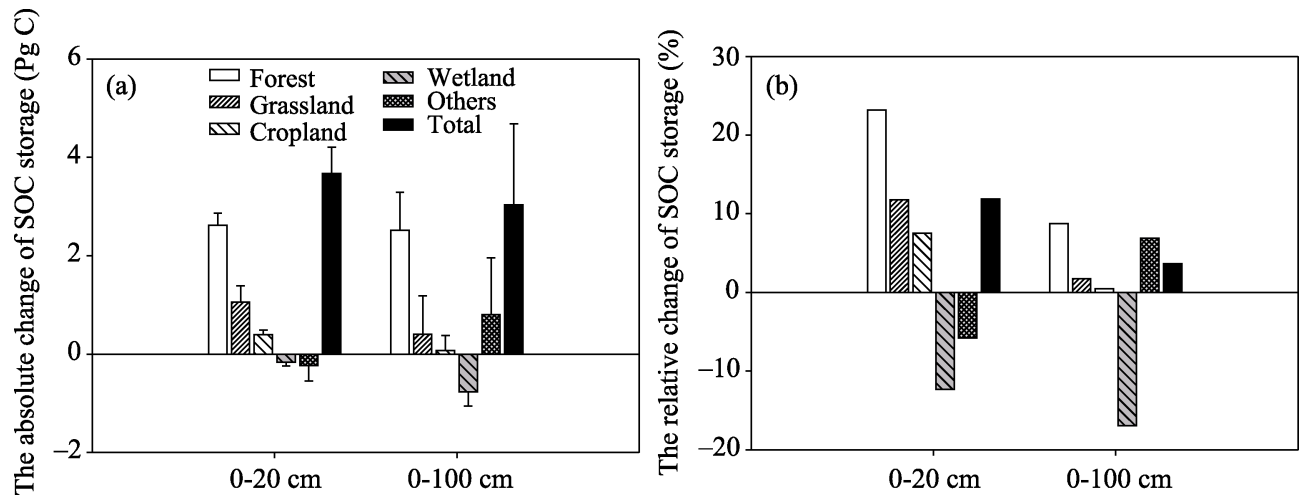

Figure 5 Absolute (a, Pg C) and relative (b, \%) changes in soil organic carbon (SOC) storage across different ecosystems of China

In forests, grasslands, and croplands, SOC storage increased during the past three decades, being the highest in forests and the lowest in croplands. For forests, the net increases in SOC density and storage were higher in the topsoil $(0-20 \mathrm{~cm})\left(0.96 \pm 0.09 \mathrm{~kg} \mathrm{C} \mathrm{m}^{-2}\right.$ and $2.62 \pm$ $0.24 \mathrm{Pg} \mathrm{C}$, respectively) than in the $0-100 \mathrm{~cm}$ soil layer $\left(0.92 \pm 28 \mathrm{~kg} \mathrm{C} \mathrm{m}^{-2}\right.$ and $2.52 \pm 0.77$ $\mathrm{Pg} \mathrm{C}$, respectively). The net increases in SOC storage in the $0-20 \mathrm{~cm}$ and $0-100 \mathrm{~cm}$ soil layers of grasslands were estimated as $1.06 \pm 0.33$ and $0.40 \pm 0.78 \mathrm{Pg} \mathrm{C}$, with an average rate of $0.035 \pm 0.011$ and $0.013 \pm 0.026 \mathrm{Pg} \mathrm{C} \mathrm{yr}^{-1}$, respectively. Compared to forests and grasslands, the increase in SOC storage in croplands was relative small. Contrarily, SOC density in the $0-20 \mathrm{~cm}$ and $0-100 \mathrm{~cm}$ soil layers of wetlands decreased by about $1.16 \pm 0.51$ and $5.29 \pm 2.02 \mathrm{~kg} \mathrm{C} \mathrm{m}^{-2}$, respectively, resulting in a loss of SOC storage in the last three decades $(0.17 \pm 0.07$ and $0.76 \pm 0.29 \mathrm{Pg} \mathrm{C}$, respectively).

\subsection{Changes in SOC storage in different regions}

From the 1980 s to the 2010 s, SOC density and storage increased in most regions (Table 3 ). Regarding the topsoil $(0-20 \mathrm{~cm})$, SOC density increased the most in cold humid regions (R1) $\left(2.84 \pm 0.56 \mathrm{~kg} \mathrm{C} \mathrm{m}^{-2}\right)$, and SOC storage increased the most in mid-subtropical humid regions (R16) $(1.03 \pm 0.14 \mathrm{Pg} \mathrm{C})$. In the $0-100 \mathrm{~cm}$ soil layer, SOC density and storage increased the most in Qinghai-Tibet Plateau temperate arid regions (R10; $3.33 \pm 0.77 \mathrm{~kg} \mathrm{C} \mathrm{m}^{-2}$ and $1.23 \pm 0.29 \mathrm{Pg} \mathrm{C}$, respectively). In temperate semi-arid regions (R4), temperate arid regions (R5), Qinghai-Tibet Plateau subfrigid semi-arid regions (R12), and tropical humid regions (R18), SOC density and storage decreased in the $0-20 \mathrm{~cm}$ and $0-100 \mathrm{~cm}$ soil layers, with $\mathrm{R} 5$ presenting the greatest decrease in both indices.

Forests SOC storage increased in most ecological regions but slightly decreased in temperate semi-humid regions (R3), temperate semi-arid regions (R4), temperate arid regions (R5), warm temperate arid regions (R6), and tropical humid regions (R18) (Tables 4 and 5). In grasslands, there was a general increase in SOC storage, although it decreased in some regions in northern China (Tables 4 and 5). Grasslands in Qinghai-Tibet Plateau and in southern China played important roles in SOC accumulation. For croplands, SOC storage slightly increased in the main grain product areas (e.g., temperate humid regions (R2), warm temperate semi-humid regions (R8), and north subtropical humid regions (R14)) (Tables 4 and 5). On the contrary, SOC storage in wetlands decreased in most ecological regions (Tables 4 and 5). 


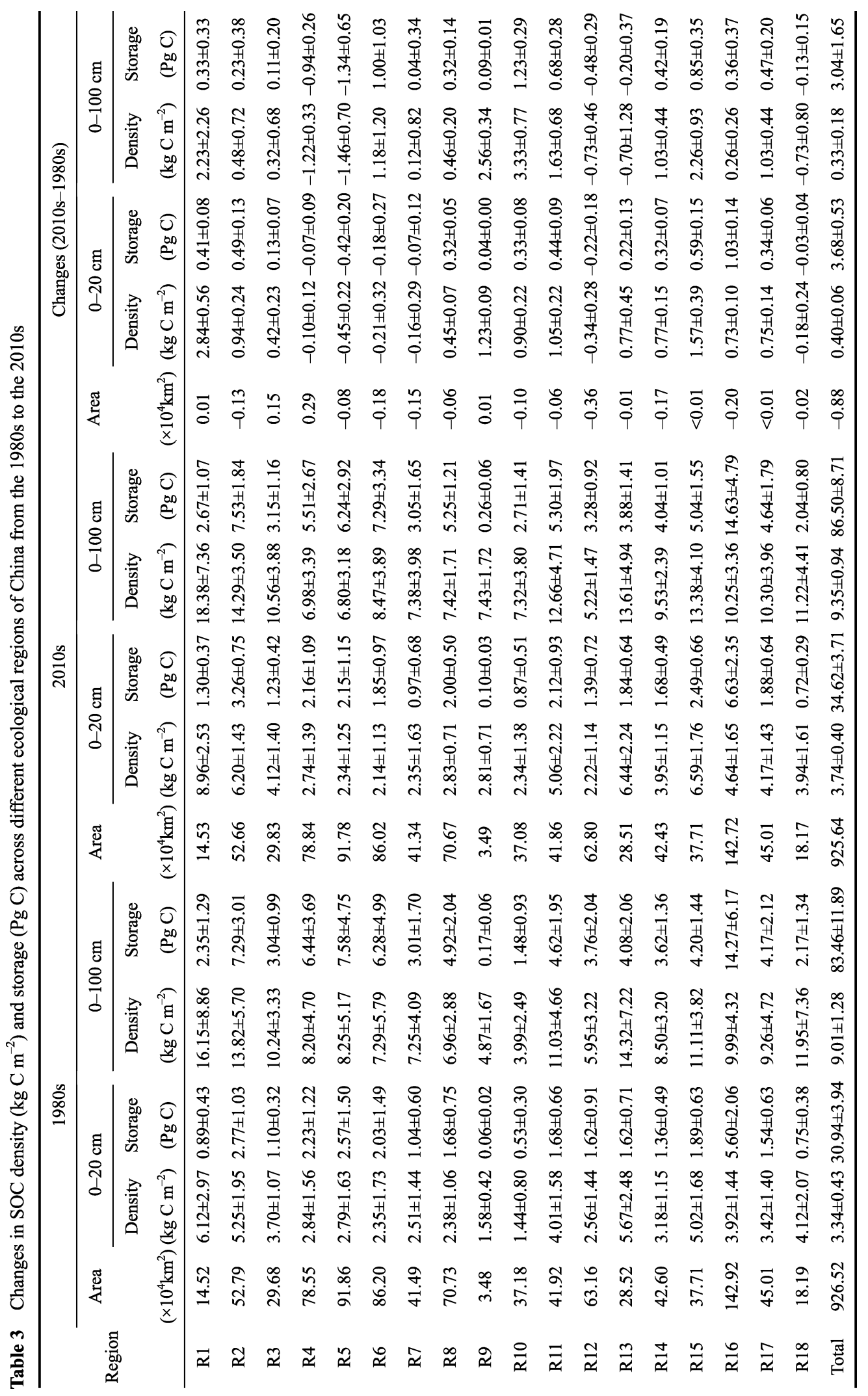




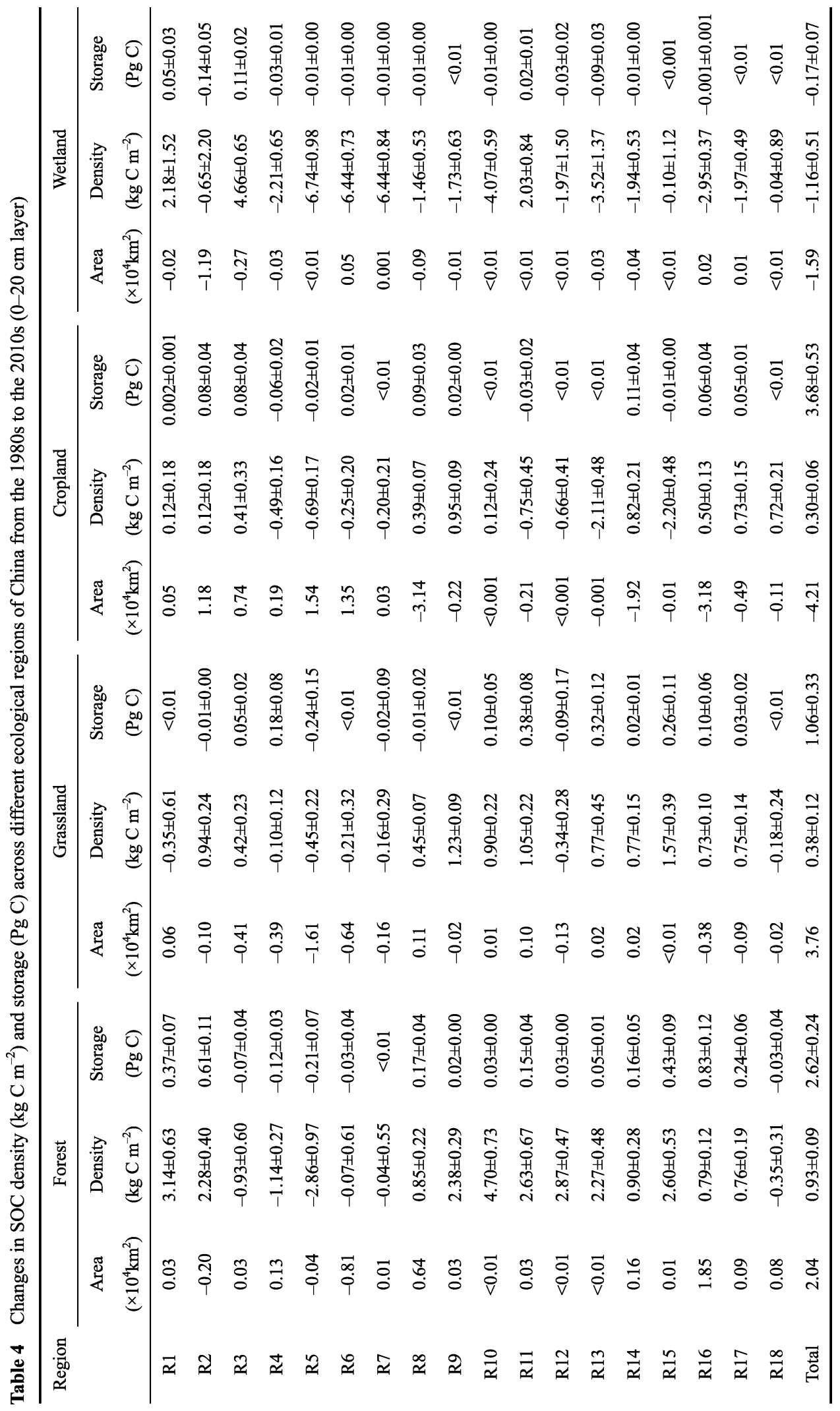




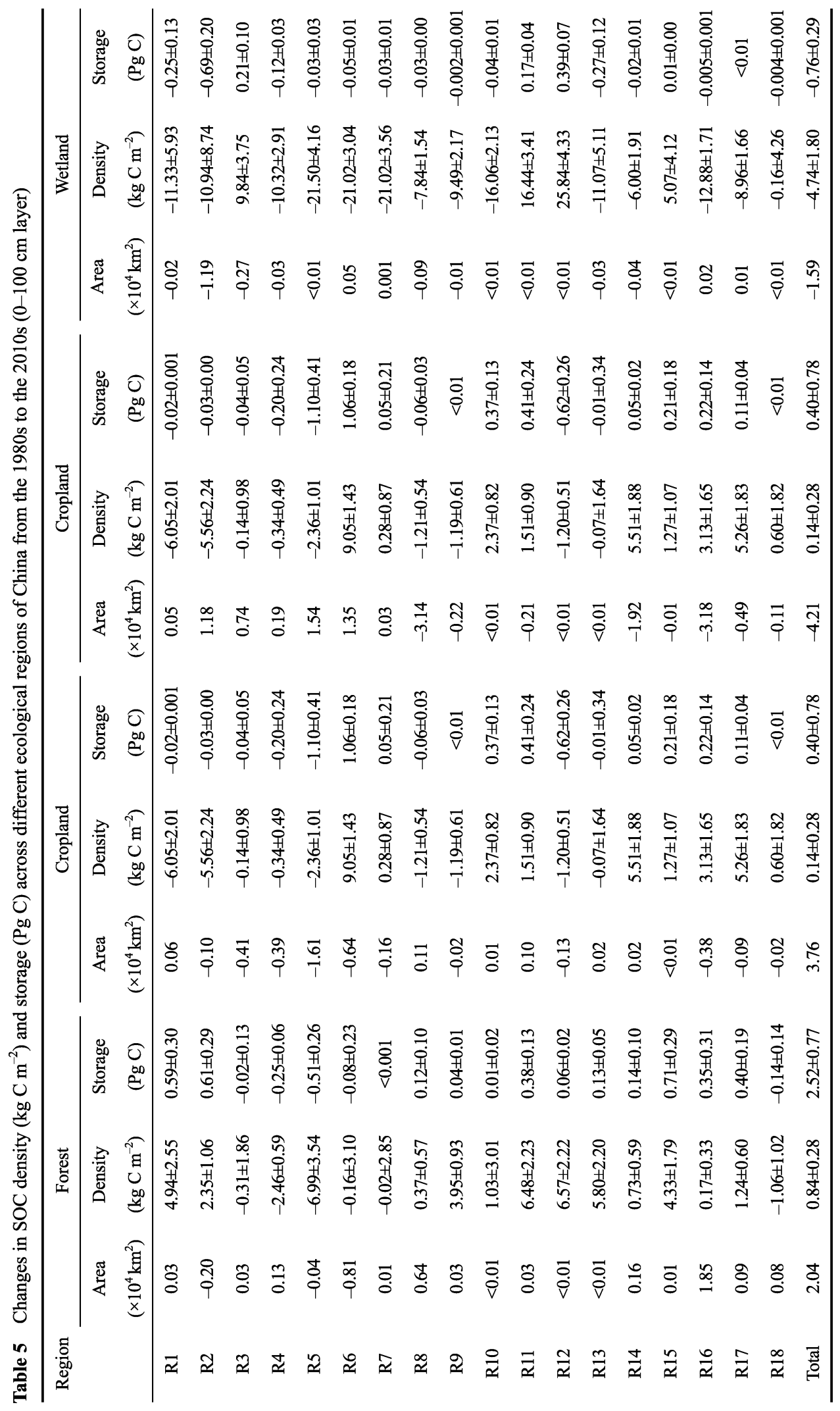




\section{Discussion}

\subsection{Uncertainty of SOC storage estimation in the $1980 \mathrm{~s}$ and $2010 \mathrm{~s}$}

The SOC storage $(83.46 \pm 11.89 \mathrm{Pg} \mathrm{C}$ in the $1980 \mathrm{~s}$ and $86.50 \pm 8.71 \mathrm{Pg} \mathrm{C}$ in the $2010 \mathrm{~s})$ and average densities $\left(9.01 \pm 1.28 \mathrm{~kg} \mathrm{C} \mathrm{m}^{-2}\right.$ in the $1980 \mathrm{~s}$ and $9.35 \pm 0.94 \mathrm{~kg} \mathrm{C} \mathrm{m}^{-2}$ in the $\left.2010 \mathrm{~s}\right)$ estimated for the $0-100 \mathrm{~cm}$ soil layer in China were close to the values obtained in most recent studies (Li et al., 2003; Xu et al., 2015), although higher than in Pan (1999), and lower than in Fang et al. (1996) (Table 1). Differences in soil datasets might be the main factor accounting for the variation across SOC storage studies in China. For example, while some studies used data from the first national soil survey (1958-1963) to estimate SOC storage (Fang et al., 1996), others used SNSSC data (1979-1985), or combined SNSSC data with new data (Wu et al., 2003; Yang et al., 2007). Considering the large changes in land-use in China from the 1980s to the 2010s, we combined the SNSSC data with data published during 2004-2014 to estimate SOC storage in the two periods, simultaneously. The datasets used in the present study contained the most recent and comprehensive information, and, therefore, might reflect the current status of SOC storage in China. Differences in SOC storage estimation methods might also have contributed to the wide range of SOC storage estimates. Because changes in climate, vegetation, and land-use are important factors influencing the spatial distribution of SOC storage (Post et al., 1982; Cao and Woodward, 1998; Jobbágy and Jackson, 2000; Yang et al., 2007; Wiesmeier et al., 2012), we first estimated SOC storage across the different ecosystems within each ecological region, and then summed these values to estimate SOC storage at the national scale, to improve the accuracy of estimation. Another factor that might have contributed to the large differences in SOC storage estimates among several studies are the methods used to optimize critical parameters (e.g. soil bulk density, rock fragment volume, soil depth, and area). Additionally, the small number of soil profiles from the northwestern regions might have reduced estimation accuracy to some extent, and, therefore, field measurements in these regions should be strengthened in future studies.

\subsection{Changes of SOC storage in different ecosystems from the $1980 \mathrm{~s}$ to the $2010 \mathrm{~s}$}

China's forest soils represented the largest SOC sink over the past three decades, although SOC storage in forests declined in some ecological regions (Tables 3 and 4). Overall, the net increase in SOC storage in the $0-100 \mathrm{~cm}$ soil layer $(2.52 \pm 0.77 \mathrm{Pg} \mathrm{C}$, with an average increasing rate of $0.084 \pm 0.026 \mathrm{Pg} \mathrm{C} \mathrm{yr}^{-1}$ ) accounted for $83 \%$ of soil $\mathrm{C}$ sequestration capacity in Chinese terrestrial ecosystems, which was consistent with the SOC dynamics reported in Xie et al. (2007), Piao et al. (2009), and Yang et al. (2014b). Xie et al. (2007) estimated SOC storage changes based on the mean rate of forest SOC accumulation, Piao et al. (2009) explored changes of SOC storage through regression equations of SOC density on climatic factors and biomass, and Yang et al. (2014) used 501 paired plots to directly evaluate changes in the $0-10 \mathrm{~cm}$ layer. Considering method and data source, our estimates should be more accurate and more comprehensive, and the higher estimates in our study could be partly attributed to differences in the study period. Since most reforestation projects started in the 1980s, forest C sequestration (in both vegetation and soil) increased with tree growth (Zhou et al., 2006; Luyssaert et al., 2008). Despite being relatively more stable than top soils $(0-20 \mathrm{~cm})$, deep soils $(20-100 \mathrm{~cm})$ might have played a role in forest $\mathrm{C}$ sequestration, which should be further studied.

Grassland soils in China acted as a weak C sink in the 1980s-2010s period, with SOC 
storage increasing only $1.06 \pm 0.33$ and $0.40 \pm 0.78 \mathrm{Pg} \mathrm{C}$ in the $0-20 \mathrm{~cm}$ and $0-100 \mathrm{~cm}$ soil layers, respectively. These estimates were consistent with those of Piao et al. (2007), who used regression of SOC density on climatic factors and NDVI to assess changes in Chinese grasslands SOC storage. Contrastingly, Xie et al. (2007) reported a decrease in the SOC storage of China grasslands, which acted as a $\mathrm{C}$ source, based on the rate of SOC loss driven by vegetation degradation in Tibetan grasslands. These differences might have resulted from the different approaches used to estimate SOC storage in China's grasslands (Fang et al., 2010). In this study, there was an overall increase in SOC storage in China's grasslands, although it decreased in some northern grasslands (Table 5). Previous studies reported an increase in the aboveground biomass in northern China's grasslands since 2001, when the government implemented measures to protect grassland resources (e.g. returning reclaimed land to grasslands, grazing exclusion, and rest grazing) (Piao et al., 2007; Piao et al., 2009; Xin et al., 2009; Ma et al., 2010). Thus the observed SOC decrease might be partly attributed to a lag in the response of SOC to increase inputs from plant biomass (Hu et al., 2016). Additionally, increases in SOC storage in China's grassland might be because of new SOM inputs from root and litter, and to a slower SOM decomposition accompanying the decrease in grasslands' temperature following the increase in aboveground biomass ( $\mathrm{He}$ et al., 2008, 2013).

Croplands had the smallest SOC increase in China over the past 30 years with topsoil $(0-20 \mathrm{~cm})$ SOC storage increasing at a rate of $0.013 \pm 0.003 \mathrm{Pg} \mathrm{C} \mathrm{yr}^{-1}$, approximately. The increase of SOC storage in the topsoil was mainly contributed to changes in agricultural practices to increase crop production, which increased soils' residues and root input (Huang et al., 2007; Xie et al., 2007; Sun et al., 2010). The return of agricultural residues to croplands has also been pointed out as an important factor contributing to SOC storage increase in some regions of China (Liu et al., 2014a). However, cropland soils in southern China, which have an intensive and long history of agricultural activity, lost SOC in the $0-100 \mathrm{~cm}$ layers even though SOC increased in the topsoil.

China's wetlands acted as substantial C sources during the 1980s and the 2010s, despite the apparent decrease in China's wetlands SOC storage because of a decrease in wetland area and SOC storage per unit area (Liu and Zhang, 2005). Although wetlands occupy only $1.6 \%-1.7 \%$ of the Chinese terrestrial ecosystems, their SOC content is much higher than in other ecosystems. The decreasing water level or the declining area of wetlands, might lead to a drastic decrease in the SOM, to which increasing soil temperature, porosity and permeability (Davidson and Janssens, 2006). Unfortunately, few studies have addressed wetlands' role as a $\mathrm{C}$ sink or source based on systematic field investigations at a national scale, an issue that still requires further studies.

\subsection{Changes of carbon storage in Chinese terrestrial ecosystems from the 1980 s to the 2010s}

Overall, the soils of Chinese terrestrial ecosystems acted as net C sink (3.04 $\pm 1.65 \mathrm{Pg} C)$ from the 1980s to the $2010 \mathrm{~s}$, with an average increasing rate of $0.101 \pm 0.055 \mathrm{Pg} \mathrm{C} \mathrm{yr}^{-1}$. Our estimates were slightly higher than that of Piao et al. (2009), which used an inventory-satellitebased and process-based methods to estimate the $\mathrm{C}$ sink rate $\left(0.075 \mathrm{Pg} \mathrm{C} \mathrm{yr}^{-1}\right)$. Based on China's ground observation data, Fang et al. (2007) estimated that terrestrial vegetation sunk

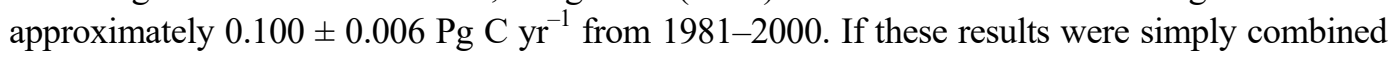
(vegetation and soil $\mathrm{C}$ sink rates), the net $\mathrm{C}$ sink in Chinese terrestrial ecosystems would be 
$0.201 \pm 0.061 \mathrm{Pg} \mathrm{C} \mathrm{yr}^{-1}$, which is similar to that of European terrestrial ecosystems (Peters et al., 2010), but lower than that of terrestrial ecosystems in the United States (Xiao et al., 2011) (Figure 6). The amount of $\mathrm{C}$ sink in Chinese terrestrial ecosystems may offset about $14.85 \%-27.79 \%$ of the $\mathrm{CO}_{2}$ emissions from fossil fuel during the $1980 \mathrm{~s}-2010 \mathrm{~s}$ period in China (C emission data in China were retrieved from http://www.globalcarbonproject.org.)
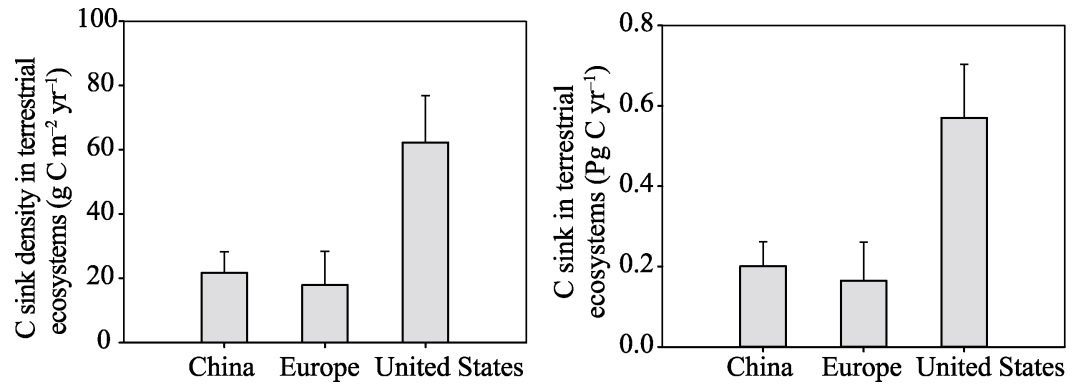

Figure 6 Overall terrestrial ecoystems C sink in China, Europe, and the United States (Data for Europe and United States are derived from Peters et al., 2010 and Xiao et al., 2011)

\section{Conclusions}

This is the first estimate of soil $\mathrm{C}$ sink in Chinese terrestrial ecosystems at a national scale based on field measured data. The SOC storage $(0-100 \mathrm{~cm})$ in China increased $3.04 \pm 1.65$ $\mathrm{Pg} \mathrm{C}$, with an average increasing rate of $0.101 \pm 0.055 \mathrm{Pg} \mathrm{C} \mathrm{yr}^{-1}$, accompanying the increase rate of $0.100 \pm 0.006 \mathrm{Pg} \mathrm{C} \mathrm{yr}^{-1}$ in vegetation $\mathrm{C}$ storage, because of a series of key ecological restoration projects and changes in agricultural practices. Increase in SOC storage was the largest in forest soils, followed by grasslands and croplands, but decreased in wetlands from the 1980 s to the 2010s. Thus, both public and government should pay more attention to the protection of wetlands' vegetation and soil. Combining soil and vegetation $\mathrm{C}$ sink capacity, China's terrestrial ecosystems might have absorbed $14.85 \%-27.79 \%$ of the fossil fuel $\mathrm{C}$ emissions during the 1980s-2010s. Overall, our findings suggested that the large C sequestration potential of China's terrestrial ecosystems is because of the increase in afforestation and vegetation restoration programs implemented in the past decades, and these ecosystems might play additional important roles in $\mathrm{C}$ sequestration in the scenario of global warming.

\section{Acknowledgements}

We thank National Climate Center for providing the data of their simulations by regional climate model, and appreciate the data share from National Data Sharing Infrastructure of Earth System Science (http://www.geodata.cn/).

\section{References}

Batjes N H, 1996. Total carbon and nitrogen in the soils of the world. European Journal of Soil Science, 47(2): 151-163.

Bohn H L, 1982. Estimate of organic carbon in world soils. Soil Science Society of America Journal, 46(5): $1118-1119$.

Cao M K, Woodward F I, 1998. Net primary and ecosystem production and carbon stocks of terrestrial ecosystems and their responses to climate change. Global Change Biology, 4(2): 185-198.

Cox P M, Betts R A, Jones C D et al., 2000. Acceleration of global warming due to carbon-cycle feedbacks in a coupled climate model. Nature, 408(6813): 184-187.

Davidson E A, Janssens I A, 2006. Temperature sensitivity of soil carbon decomposition and feedbacks to climate 
change. Nature, 440(7081): 165-173.

Eswaran H, Vandenberg E, Reich P, 1993. Organic carbon in soils of the world. Soil Science Society of America Journal, 57(1): 192-194.

Fang J Y, Guo Z D, Piao S L et al., 2007. Terrestrial vegetation carbon sinks in China, 1981-2000. Science in China Series D: Earth Sciences, 50(9): 1341-1350.

Fang J Y, Liu G H, Xu S L, 1996. Soil carbon pool in China and its global significance. Journal of Environmental Sciences, 8(2): 249-254. (in Chinese)

Fang J Y, Yang Y H, Ma W H et al., 2010. Ecosystem carbon stocks and their changes in China's grasslands. Science China Life Sciences, 53(7): 757-765.

Fu B J, Liu G H, Ma K M et al., 2001. Scheme of ecological regionalization in China. Acta Ecologica Sinica, 21(1): 1-6. (in Chinese)

Hayes D J, Turner D P, Stinson G et al., 2012. Reconciling estimates of the contemporary North American carbon balance among terrestrial biosphere models, atmospheric inversions, and a new approach for estimating net ecosystem exchange from inventory-based data. Global Change Biology, 18(4): 1282-1299.

He N P, Wang R M, Gao Y et al., 2013. Changes in the temperature sensitivity of SOM decomposition with grassland succession: Implications for soil C sequestration. Ecology and Evolution, 3(15): 5045-5054.

He N P, Yu Q, Wu L et al., 2008. Carbon and nitrogen store and storage potential as affected by land-use in a Leymus chinensis grassland of northern China. Soil Biology \& Biochemistry, 40(12): 2952-2959.

$\mathrm{Hu}$ Z M, Li S G, Guo Q et al., 2016. A synthesis of the effect of grazing exclusion on carbon dynamics in grasslands in China. Global Change Biology, 22(4): 1385-1393.

Huang Y, Sun W J, 2006. Changes in topsoil organic carbon of croplands in mainland China over the last two decades. Chinese Science Bulletin, 51(15): 1785-1803.

Huang Y, Zhang W, Sun W J et al., 2007. Net primary production of Chinese croplands from 1950 to 1999. Ecological Applications, 17(3): 692-701.

Janssens I A, Freibauer A, Ciais P et al., 2003. Europe's terrestrial biosphere absorbs 7 to $12 \%$ of European anthropogenic $\mathrm{CO}_{2}$ emissions. Science, 300(5625): 1538-1542.

Jobbágy E G, Jackson R B, 2000. The vertical distribution of soil organic carbon and its relation to climate and vegetation. Ecological Applications, 10(2): 423-436.

Lal R, 2004a. Offsetting China's $\mathrm{CO}_{2}$ emissions by soil carbon sequestration. Climatic Change, 65(3): $263-275$.

Lal R, 2004b. Soil carbon sequestration impacts on global climate change and food security. Science, 304(5677): 1623-1627.

Li K R, Wang S Q, Cao M K, 2003. Carbon storage in vegetation and soil of China. Science in China Series D: Earth Sciences, 33(1): 72-80. (in Chinese)

Liang W, Yang Y T, Fan D M et al., 2015. Analysis of spatial and temporal patterns of net primary production and their climate controls in China from 1982 to 2010. Agricultural and Forest Meteorology, 204: 22-36.

Liu C, Lu M, Cui J et al., 2014a. Effects of straw carbon input on carbon dynamics in agricultural soils: A meta-analysis. Global Change Biology, 20(5): 1366-1381.

Liu W H, Zhu J J, Jia Q Q et al., 2014b. Carbon sequestration effects of shrublands in Three-North Shelterbelt Forest region, China. Chinese Geographical Science, 24(4): 444-453.

Liu Z G, Zhang K M, 2005. Wetland soils carbon stock in the Sanjiang plain. Journal of Tsinghua University (Science and Technology), 45(6): 788-791. (in Chinese)

Luyssaert S, Schulze E D, Börner A et al., 2008. Old-growth forests as global carbon sinks. Nature, 455(7210): $213-215$.

Ma A N, He N P, Yu G R et al., 2016. Carbon storage in Chinese grassland ecosystems: Influence of different integrative methods. Scientific Reports, 6: srep21378. doi: 10.1038/srep21378.

Ma W H, Fang J Y, Yang Y H et al., 2010. Biomass carbon stocks and their changes in northern China's grasslands during 1982-2006. Science China Life Sciences, 53(7): 841-850.

Ni J, 2001. Carbon storage in terrestrial ecosystems of China: Estimates at different spatial resolutions and their responses to climate change. Climatic Change, 49(3): 339-358.

Ni J, 2002. Carbon storage in grasslands of China. Journal of Arid Environments, 50(2): 205-218.

Ni J, 2013. Carbon storage in Chinese terrestrial ecosystems: Approaching a more accurate estimate. Climatic Change, 119(3): 905-917.

Ouyang Z Y, Zheng H, Xiao Y et al., 2016. Improvements in ecosystem services from investments in natural capital. Science, 352(6292): 1455-1459.

Pacala S W, Hurtt G C, Baker D et al., 2001. Consistent land- and atmosphere-based US carbon sink estimates. Science, 292(5525): 2316-2320.

Pan G X, 1999. Study on carbon reservoir in soils of China. Bulletin of Science and Technology, 15(5): 330-332.

Pan G X, Xu X W, Smith P et al., 2010. An increase in topsoil SOC stock of China's croplands between 1985 and 2006 revealed by soil monitoring. Agriculture Ecosystems \& Environment, 136(1): 133-138.

Pan Y D, Birdsey R A, Fang J Y et al., 2011. A large and persistent carbon sink in the world's forests. Science, 333(6045): 988-993.

Peng C H, Apps M J, 1997. Contribution of China to the global carbon cycle since the last glacial maximum: Reconstruction from palaeovegetation maps and an empirical biosphere model. Tellus Series B-Chemical and Physical Meteorology, 49(4): 393-408.

Peng S L, Wen D, He N P et al., 2016. Carbon storage in China's forest ecosystems: Estimation by different 
integrative methods. Ecology and Evolution, 6(10): 3129-3145.

Peters W, Krol M C, van Der Werf G R et al., 2010. Seven years of recent European net terrestrial carbon dioxide exchange constrained by atmospheric observations. Global Change Biology, 16(4): 1317-1337.

Piao S L, Fang J Y, Ciais P et al., 2009. The carbon balance of terrestrial ecosystems in China. Nature, 458(7241): 1009-1014.

Piao S L, Fang J Y, Zhou L M et al., 2007. Changes in biomass carbon stocks in China's grasslands between 1982 and 1999. Global Biogeochemical Cycles, 21(2). doi: 10.1029/2005GB002634.

Post W M, Emanuel W R, Zinke P J et al., 1982. Soil carbon pools and world life zones. Nature, 298(5870): $156-159$.

Schrumpf M, Schulze E D, Kaiser K et al., 2011. How accurately can soil organic carbon stocks and stock changes be quantified by soil inventories? Biogeosciences, 8(5): 1193-1212.

Sun W J, Huang Y, Zhang W et al., 2010. Carbon sequestration and its potential in agricultural soils of China. Global Biogeochemical Cycles, 24(3). doi: 10.1029/2009GB003484.

Wang S L, Huang M, Shao X M et al., 2004. Vertical distribution of soil organic carbon in China. Environmental Management, 33(1): S200-S209.

Wang S Q, Tian H Q, Liu J Y et al., 2003. Pattern and change of soil organic carbon storage in China: 1960s-1980s. Tellus Series B-Chemical and Physical Meteorology, 55(2): 416-427.

Wang S Q, Zhou C H, 1999. Estimating soil carbon reservoir of terrestrial ecosystem in China. Geographical Research, 18(4): 349-356. (in Chinese)

Wang S Q, Zhou C H, Li K R et al., 2000. Analysis on spatial distribution characteristics of soil organic carbon reservoir in China. Acta Geographica Sinica, 55(5): 533-544. (in Chinese)

Wang Y F, Fu B J, Lu Y H et al., 2011. Effects of vegetation restoration on soil organic carbon sequestration at multiple scales in semi-arid Loess Plateau, China. Catena, 85(1): 58-66.

Wiesmeier M, Sporlein P, Geuss U et al., 2012. Soil organic carbon stocks in southeast Germany (Bavaria) as affected by land use, soil type and sampling depth. Global Change Biology, 18(7): 2233-2245.

Wu B F, Yuan Q Z, Yan C Z et al., 2014. Land cover changes of China from 2000 to 2010. Quaternary Sciences, 34(4): 723-731. (in Chinese)

Wu H B, Guo Z T, Peng C H, 2003. Distribution and storage of soil organic carbon in China. Global Biogeochemical Cycles, 17(2). doi: 10.1029/2001GB001844.

Xiao J F, Zhuang Q L, Law B E et al., 2011. Assessing net ecosystem carbon exchange of U.S. terrestrial ecosystems by integrating eddy covariance flux measurements and satellite observations. Agricultural and Forest Meteorology, 151(1): 60-69.

Xie X L, Sun B, Zhou H Z et al., 2004. Soil carbon stocks and their influencing factors under native vegetations in China. Acta Pedologica Sinica, 41(5): 687-699. (in Chinese)

Xie Z B, Zhu J G, Liu G et al., 2007. Soil organic carbon stocks in China and changes from 1980s to 2000s. Global Change Biology, 13(9): 1989-2007.

Xin X P, Zhang B H, Li G et al., 2009. Variation in spatial pattern of grassland biomass in China from 1982 to 2003. Journal of Natural Resources, 24(9): 1582-1592. (in Chinese)

$\mathrm{Xu} \mathrm{L}, \mathrm{He}$ N P, Yu G R et al., 2015. Differences in pedotransfer functions of bulk density lead to high uncertainty in soil organic carbon estimation at regional scales: Evidence from Chinese terrestrial ecosystems. Journal of Geophysical Research: Biogeosciences, 120(8): 1567-1575.

Xu L, Yu G R, He N P et al., 2018. Carbon storage in China's terrestrial ecosystems: A synthesis. Scientific Reports, 8: srep2806. doi: 10.1038/s41598-018-20764-9.

Xu X L, Cao M K, Li K R, 2007. Temporal-spatial dynamics of carbon storage of forest vegetation in China. Progress in Geography, 26(6): 1-10. (in Chinese)

Yang H F, Mu S J, Li J L, 2014a. Effects of ecological restoration projects on land use and land cover change and its influences on territorial NPP in Xinjiang, China. Catena, 115: 85-95.

Yang Y H, Fang J Y, Ma W H et al., 2010. Soil carbon stock and its changes in northern China's grasslands from 1980s to 2000s. Global Change Biology, 16(11): 3036-3047.

Yang Y H, Li P, Ding J Z et al., 2014b. Increased topsoil carbon stock across China's forests. Global Change Biology, 20(8): 2687-2696.

Yang Y H, Li W H, Zhu C G et al., 2017. Impact of land use/cover changes on carbon storage in a river valley in arid areas of Northwest China. Journal of Arid Land, 9(6): 879-887.

Yang Y H, Mohammat A, Feng J M et al., 2007. Storage, patterns and environmental controls of soil organic carbon in China. Biogeochemistry, 84(2): 131-141.

Yu D S, Shi X Z, Wang H J et al., 2007. National scale analysis of soil organic carbon storage in China based on Chinese soil taxonomy. Pedosphere, 17(1): 11-18.

Yu G R, Li X R, Wang Q F et al., 2010. Carbon storage and its spatial pattern of terrestrial ecosystem in China. Journal of Resources and Ecology, 1(2): 97-109.

Zheng Y, Niu Z, Gong P et al., 2013. Preliminary estimation of the organic carbon pool in China's wetlands. Chinese Science Bulletin, 58(6): 662-670. (in Chinese)

Zhou G Y, Liu S G, Li Z et al., 2006. Old-growth forests can accumulate carbon in soils. Science, 314(5804): 1417-1417.

Zhou Y R, Yu Z L, Zhao S D, 2000. Carbon storage and budget of major Chinese forest types. Acta Phytoeclolgica Sinica, 24(5): 518-522. (in Chinese) 